\title{
Medication logistics in Public Healthcare: Model adopted by the State of Minas Gerais in Brazil
}

\author{
Lívia Maria de Pádua Ribeiro ${ }^{1 \star}$, José Roberto Pereira ${ }^{1}$ and Fernando Gustavo da Silva \\ Quirino $^{2}$
}

${ }^{1}$ Department of Administration and Economy, Federal University of Lavras, Brazil.

${ }^{2}$ Foundation João Pinheiro, Government of the State of Minas Gerais, Brazil.

Accepted 25 July, 2013

\begin{abstract}
The main objectives of this study are to describe the logistic operation model adopted in relation to public politics on the acquisition and distribution of medications by the Government of the State of Minas Gerais, in order to compare the previous model with the new model and to identify the main advantages and disadvantages of outsourcing the logistics operation in reference to the medications of the State of Minas Gerais, Brazil. In order to perform this study, we adopted the quantitative research, performing document investigations and interviews with the managers of the State Department of Health of Minas Gerais (SES-MG) directly involved in the logistic operation processes of medications in the State of Minas Gerais. The results show a new medication logistic model adopted by the State of Minas Gerais, which includes the employment of a logistics operator, rationalizing costs and bringing quality to the servicesprovided in the performance of logistic activities. However, despite the efforts of the SES-MG in Brazil, there are still difficulties in the SES-MG position while manager of outsource employments. SES-MG did not present much experience with this type of employment. However, there are some challenges to be met.
\end{abstract}

Key words: Logistics, medications, public healthcare.

\section{INTRODUCTION}

Since the end of the 1970's, the reform of the State became a term of order in almost the entirety of the world (Abrucio, 2005). The States, previously seated within bureaucratic public administration logic, perform a series of changes, thus developing a new paradigm: the managerial pubic administration. Many factors have led the States to performing these changes. Among the main motives, we may list the fiscal adjustment and the budgetary restrictions (Bresser-Pereira, 2005; Denhardt, 2012; Osborne and Gaebler, 1997). Public administration, in a managerial context, seeks to improve the quality of public expenses and increasing its performance. All this effort must go through the modernization of the public management, including phases of logistic processes, such as purchasing management, transportation, stock and storing, among other (Tridapalli et al., 2011).

The demand for an efficient logistic process intensifies when its related to public healthcare. Many studies referent to logistics and management of the healthcare supply chain (Bossert et al., 2007 Chindove and Mdege, 2012; Nwokah et al., 2009; Tetteh, 2009) have shown the Governments' commitment to improve medication distribution, even if through partnerships and employment of private companies. It is not different in Brazil. Politics and planning have sought the efficiency of the logistic system

*Corresponding author. E-mail: livia.padua@ig.com.br. 
in public healthcare, seeking to directly impact the citizens' life quality.

The main objectives of this study were describing the logistic operation model adopted in relation to public politics on the acquisition and distribution of medications by the Government of the State of Minas Gerais, in order to compare the previous model with the new model, and identify the main advantages and disadvantages of outsourcing the logistics operation referent to the medications of the State of Minas Gerais, Brazil.

The study consists in a qualitative and descriptive research. In order to reach the objectives proposed, we performed a bibliographical and documental research. In regard to the data collecting techniques, we developed interviews with managers and workers involved in the change of this logistic process of the State Department of Health of Minas Gerais (SES-MG) in Brazil.

The results show that the adoption of the outsourced logistics operator in the State of Minas Gerais rationalized the costs and brought quality to the services provided in the effort of the logistic activities. However, despite the efforts of the SES-MG in Brazil, there are still difficulties in the SES-MG position while manager of outsourced contracts. The SES-MG does not possess much experience with this type of employment. However, there are a few challenges to be met.

\section{The medication logistics}

Traditional logistics concepts may be found in Ballou (2001) and Christopher (2001). A widely divulged concept is that of the Council of Logistics Management cited by Ballou (2001, p. 21), which defines the logistic as a "process of planning, implementation and control of the efficient and economically effective flow of raw material, stock in process, finished products and relative information from the point of origin to the point of consumption, with the purpose of attending the clients' demands."

As the organizations integrate their efforts to offer their clients more than their products, and present responsibilities in collaboration with their partners, whether they are suppliers, intermediates, service providers, distributers, among others, the evolution of logistics occurs, the supply chain management. In this context, logistics presents an internal integration and the supply chain management, an external integration which connects the suppliers to the final consumers (Mentzer et al., 2011).

This study was limited to medication logistics, focusing on storage and distribution instead of studying the coordination and synchronicity of the network of players involved in the businesses inside the supply chain. The medication logistics in the private sector is quite peculiar, since it has the Government as a big corporative buyer. In practice, this means that the State is a significant player in the healthcare market, constituting voluminous acquisitions (Machline and Amaral, 2006).

Such weight confers considerable bargaining power with pharmaceutical companies to the Governments. Despite this fact, some industries do not negotiate directly with the State, being intermediated by wholesalers and distributers. This phenomenon may be explained by deals struck between the industry and its distributing channels, especially when it comes to patented formulas (Oliveira et al., 2006).

Oliveira et al. (2006) also explain that the public laboratories are other players in this market. The Governments also invest in the production of medications, which are produced and freely distributed through public hospitals or distribution programs in health clinics. In general, medications are researched and produced for diseases of little commercial appeal or vaccines for traditional campaigns. Figure 1 presents the medication logistics in public healthcare.

According to Buss (2000), in the last decades, public healthcare in Brazil has been advancing. A few important transformations may be detected, such as the creation of the Central Medication (CEME), the regulation of Brazilian Public Health Care System (SUS) the approval of the Brazilian National Drug Policy (PNM), the creation of the Brazilian Health Surveillance Agency (ANVISA), the publication of the Generics Law in Brazil, the performance of the Conference on Medicinal and Pharmaceutical Care, the creation of the Department of Pharmaceutical Care and Strategic Inputs (DAF), and the approval of the Brazilian Policy for Pharmaceutical Care (Pnaf) (Portela et al., 2010; Pan American Health Organization/World Health Organization, 2005).

In addition, Constitution of the Federative Republic of Brazil of 1988, in articles 6, 196 and 200, universalizes the right to healthcare, as well as describes a series of norms on the right to healthcare, including the issue of medication distribution as a continuous politic in the State (Sarlet, 2007).

\section{Purchase/Receiving}

According to Viana (2000), the purchase function means to seek and provide the delivery of materials and services, in the specified quality, in the required quantity and in the necessary term.

Bowersox et al. (2007) explain that, initially, the purchases were an activity relegated to administrative employees or operational managers, who executed the orders of other parts of the organization. However, this vision has changed in the last decades and, the purchase function came to be considered as a strategic activity of the organizations.

Baily et al. (2000) affirms that the purchase process inside the organization has become more strategic than 


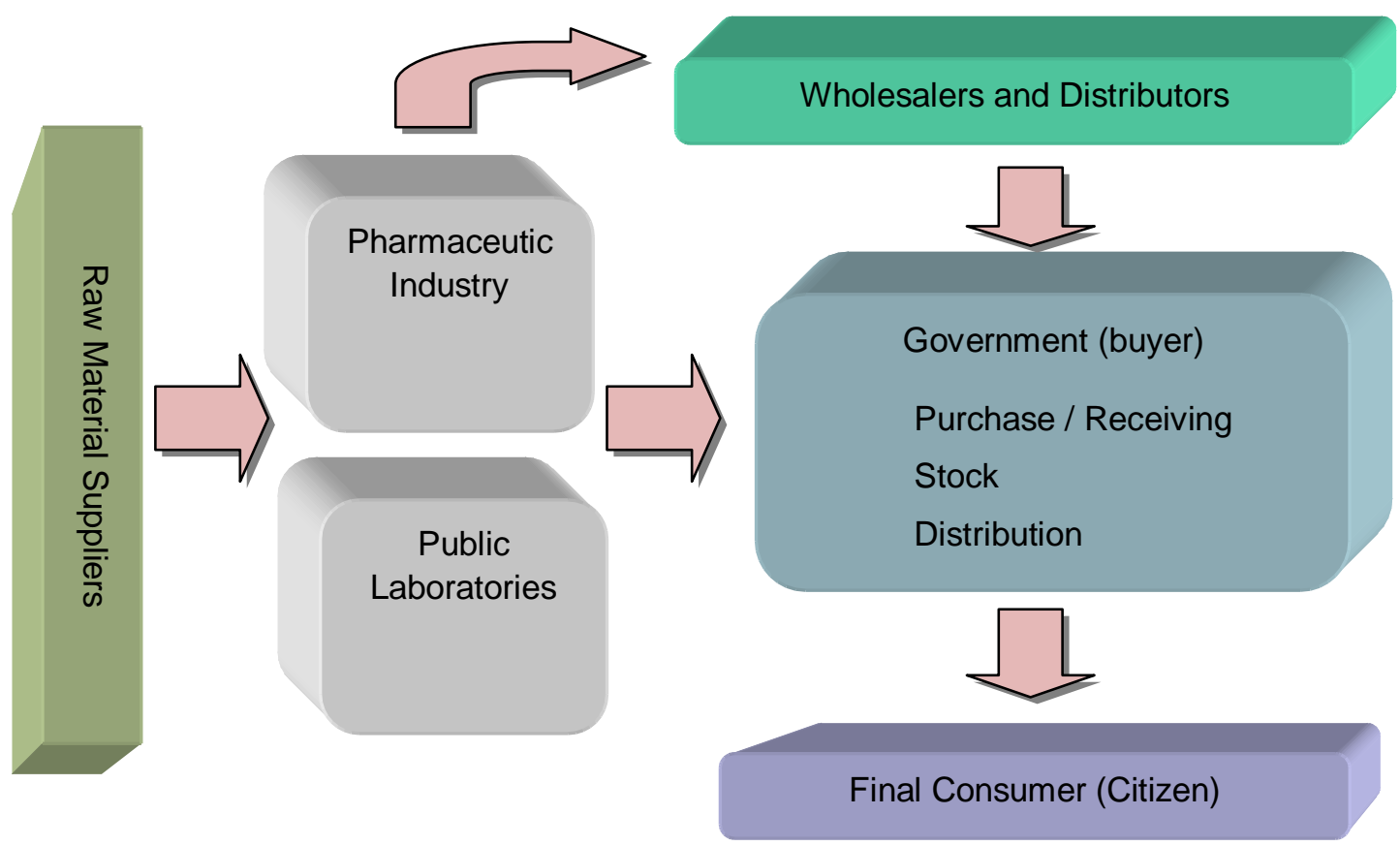

Figure 1. Medication logistics.

Source: Adapted from Machline and Amaral (2006, p. 64).

operational. For the authors, the buyers have the role to reduce the cost and also aggregate value to the product.

When we think of buying, the price factor is generally the main focus point of the purchase sector of an organization, maintaining the standard quality previously stipulated. The financial value of a good or service performs a role of high relevance at the deciding moment of the purchase. In fact, the most evident cost at the purchase decision moment is the immediate value of the acquisition. However, Baily et al. (2000) mention that a series of costs related to the benefit and the useful life of the acquired good/service, such as delivery cost, maintenance, training, inspection, storage, delays, among others, must be taken into consideration.

When dealing with public administration organizations, a particularity in good and service acquisition procedures is noted. Contrary to private organizations, which dispose of liberty at acquiring, alienating, leasing goods, hire the execution of construction and services, in the public sector, the adopted procedures must be in accordance to the law. In this case, the procedure adopted by the State is licitation, which has as modalities: the auction, public service exams, competition, price taking, the invitation and trading session (Mello, 2007). Di Pietro (1998) mentions that licitation opens to all the interested the possibility of formulating proposals among which will be selected the most convenient for the celebration of the contract. In addition, according to the author, licitation intends to provide a larger degree of clarity and equal competing conditions for potential suppliers.

\section{Transportation}

Transportation consists in a fundamental process for the organizations. The expected result for a transportation department is that the products necessary to the processes of the institutions be available in time and at the correct locations, in the adequate quantities and with the products in an adequate state for use and consumption. Bowersox et al. (2007) mentions that the transportation must be administrated in an efficient and effective manner, if not, the performance of the purchase, production and distribution sectors will fail in meeting the expectations. In the case study in question, transportation is a critical process because of the necessity of distributing and receiving many different types of medications in all of the 853 municipalities. It should be noted that transportation is fundamental to meet the logistic objective. Thus, transportation service management has the purpose that the right product be, at the right time, in the right place and at the lowest cost possible (Valente et al., 2008).

According to Fleury et al. (2003) the choice in fleet property is the most important within the most important decisions inside transportation management. In this sense, it is possible to affirm in advance that there is no precise and correct answer to which path to follow in transportation management. Everything will heavily depend in the reality of the analyzed institution.

For each organization there will be different answers to this question. Outsourcing has expanded through time. 
However, Ballow (2006) explains that outsourcing may occur with performing this transportation activity with own or hired fleet.

In referring to transportation services in Public Administration, the cost factor would be the most preponderant in fleet management, provided the required quality specifications be maintained in edict. It should be reminded that the decision in question may also involve distinct levels of outsourcing. This means that the decision of the organization will not necessarily be polarized, confronting the appropriation of the entire transportation system with the complete outsourcing of the fleet and adjacent costs. The best deliberation may be the outsourcing of only part of the system. For example, leasing the fleet and hiring drivers or, buying a fleet and outsource the maintenance, etc. With this, a deep evaluation of what is being offered by the market and the cost of each possible situation is necessary (Ballou, 2001; Fleury et al., 2003).

\section{Stock}

Bowersox et al. (2007) emphasize that the stock or storing is an important aspect of economic development. Excessive stocks represent elevated costs for the organization. The first cost is the availability of the space itself for the storage, which will be larger according to the growth of the stock. There are also costs associated to this stock, such as opportunity costs of the capital immobilized in the stock, loss possibility of perishable stocks, loss costs, theft and security, among others. There is another relevant issue considered by the client, the timing.

In this context, the discussion on outsourcing the services gains importance. An important debate these days inside the institutions is the decision between producing and buying. This dilemma shows foremost, the work specialization which occurs in contemporary society. The organizations seek a larger focus for its central activities, which demand specialized knowledge. At the same time, the tasks which are not finalistic, are managed by outsources, that is, by other institutions which specialty is the management of certain service. It is noted that such a tendency may also be observed in the public sector. Vaz and Lotta (2011, p. 119) explain that "the production of goods and services for the implementation and operation of public politics causes the State to appeal to suppliers, concessionaries and organizations of the third sector in different levels".

In the stock case, the organization may choose to buy and administer a warehouse or use a public warehouse where the outsourced company provisions the space and administers the stock. Admitting this, in order to perform a comparative analysis of the owned warehouse with the public warehouse, a full comprehension of the expected results is necessary. For Ballou (2001) the owned warehouse may offer better control and flexibility. However, Bowersox et al. (2007) explain that this type of warehouse is declining, since the organizations are seeking to reduce logistic actives.

In this sense, choosing to use the public warehouse may generate considerable advantages for the case study. Ballou (2001) refers to three main possible gains: 1) no immobilized capital; 2) lower costs; and 3) flexible location. The lowering of the opportunity costs is highlighted, mainly due to the seasonality of the demand of a few healthcare items. In addition, the public warehouse may promote a sensitive lowering to the operational costs, which comes to be shared in this storage model. Therefore, the use of a logistics operator in the public sector may bring many benefits, especially considering the low capacity of returning quick answers facing new demands, mainly because of the rigidity of the bureaucratic processes of the Brazilian public administration. The logistics operator is an organization specialized in managing and executing all or some logistic activities, in the many phases of their client supply chain, aggregating value to the clients business. In order to be considered a logistics operator, the organization must perform, simultaneously, a minimum of three activities: stock control, storage and transportation management (Ballou, 2001; Novaes, 2001).

It is important to mention, within the storage operation, the distribution center (CD), which shows the competitive advantage in various companies, such as Nike, one of the largest sporting goods companies in the world, and Alpargatas, which produces havaianas flip-flops. According to Hill (2003), the main reasons leading to the use of distribution centers (CD) are basically: reduction of lead time; delivery performance; geographic location; improvement of the service level; reduction of logistics costs, the increase market share; new level of competitiveness.

The distribution center (CD) is not a common storage facility which performs only storage services. In addition to storage services, the CD also performs services which add value to the products, such as labeling, packaging, repackaging; managing the flow of materials and information and consolidating stocks and processing orders for physical distribution. The distribution center (CD) is a large and automated deposit, designed to receive products from different suppliers, take orders and issue products in a particular region with higher speed (Bowersox et al., 2007). Nike and Alpargatas opted in using a single distribution center (CD). In 2010, in order to achieve efficient distribution in Europe, Africa and the Middle East, Nike should have opened close to twenty distribution centers. However, it decided to create a single distribution center (CD) using high technology. This decision optimized storage operations and resulted in gains. 
A major dilemma appears when deciding to expand the single distribution center (CD) or create other distribution centers. The advantage of creating new distribution centers is less freightage and more agility in delivering orders. The disadvantages are maintenance and investment of more than one distribution centers. On the other hand, the advantage of a single distribution centers is the reduction of cost with infrastructure and maintenance of the distribution centers and, as a disadvantage, we may mentioned the absence of the opportunity to lower the cost of transport (Novaes, 2001; Hill, 2003). Thus, professionals and managers involved in the logistics process of a company should always perform analysis to make such decisions.

This research, with emphasis on the public sector, also shows that a single distribution center (CD) is viable and advantageous. However, the implementation of high technology is necessary for the success of the distribution center (CD).

\section{Logistics operator}

In the 1990's, with the introduction of the Supply Chain Management concept, we also introduce the logistics operator, seeking to meet the needs of its customers in a personalized and specialized manner. This new way of working presents different characteristics, therefore not all logistics service providers may be considered as a logistics operator. In the United States, between 1990 and 1995, 100 new logistics operators were created. In Brazil, logistics operators industry gained ground in 1994, with the stabilization of the national currency and the strengthening of globalization. The logistics operator stands out for always innovating and increasing service quality (Fleury et al., 2003).

In a short time, the logistics provider expanded to the public sector, favoring the new trend of public administration in optimizing costs and improving the level of services provided to the population. This paper presents a new model of the logistics operation adopted in the Secretaria de Estado de Saúde de Minas Gerais (MG-SES) in Brazil, stimulating academics and professionals to reflecting on the advantages and disadvantages of outsourcing logistics services, as well as questioning the actions related to logistics that may be undertaken, in order to improve the performance of the public sector.

Not all logistics service providers may be considered as a logistics operator. The logistics operator offers transportation services, receiving, checking, palletizing, storage, inventory management, supply lines, packaging, order separation, kit formation, routing, order tracking, vehicle tracking, control and freight payment, logistics information management, and monitoring of logistics performance, among others (Fleury et al., 2000).
According to Lambert (1998) the logistics operator has become important in the market because logistics has become recognized as a strategic area of the company. Therefore, when a company or industry fails in planning, properly managing their logistics services and the costs of these processes, they decide to hire a logistics operator. Thus, many businesses and industries prefer to focus on its business and outsource logistics services so that this area be better planned and managed by a logistics operator, in order to obtain higher gains and competitive advantages.

According to Fleury et al. (2000), when deciding whether or not to hire a logistics operator, a few basic questions are fundamental to guide this choice. After this, we present the basic questions to be addressed in this decision-making:

- What do we expect to gain from this hiring?

- What characteristic must the logistics operator have?

- What management tools should be established?

- How to evaluate the results (success of the outsourced operation)?

Understanding the need of outsourcing and the development of this process is important to avoid problems in hiring the logistics operator.

\section{METHODOLOGY}

The present article, because of its characteristics, consists in a qualitative and descriptive research. The qualitative approach, according to Oliveira (2004, p 114), "is the type of research in which one does not have the pretense of measuring or numbering." According to Vergara (2010), the qualitative approach does not use statistical methods or techniques and its objective is the construction of a research instrument adequate to the reality. The descriptive research refers to the description of certain phenomenon or population. In this article, the main objectives were describing the logistic operation model adopted in relation to public politics on the acquisition and distribution of medication by the Government of the State of Minas Gerais, to compare the previous model with the new model, and to identify the main advantages and disadvantages from outsourcing the logistics operation in relation to the medications in the State of Minas Gerais in Brazil.

In order to achieve these objectives, a bibliographical and documental research was performed. The bibliographical research refers to the theoretic base on the subject and the documental research is characterized by the search for information which does not receive scientific treatment (Oliveira, 2004). In this investigation, we obtained information from the Integrated System Materials Management and Services (SIAD) of the State of Minas Gerais; formal and informal reports of the State Department of Health of Minas Gerais (SES-MG); documents from public archives, such as laws, resolutions, edits and decrees.

In regard to the techniques of data collection, we performed interviews with four managers and three public employees of the SES-MG in Brazil, in addition to two employees hired by the outsourced logistics operator involved in the changes in this logistics process. A script was elaborated in order to guide the interview. The interview comprised of subjective questions, in an 
Table 1. Interaction of questions proposed by Fleury et al. (2000) and interview.

\begin{tabular}{|c|c|c|c|}
\hline Subject & Interview questions & $\begin{array}{l}\text { Question proposed by } \\
\text { Fleury et al. (2000) }\end{array}$ & Interviewee \\
\hline \multirow{3}{*}{ Why hire? } & $\begin{array}{l}\text { How was the project to hire an outsourced } \\
\text { logistics operator for SES-MG designed? }\end{array}$ & \multirow{3}{*}{$\begin{array}{l}\text { What is desired from the } \\
\text { hiring? }\end{array}$} & \multirow{3}{*}{$\begin{array}{l}\text { Managers and public } \\
\text { employees of the SES- } \\
\text { MG }\end{array}$} \\
\hline & $\begin{array}{l}\text { What are the idealized advantages with the } \\
\text { change in models and hiring of a logistics } \\
\text { operator? }\end{array}$ & & \\
\hline & $\begin{array}{l}\text { What are your expectations with these } \\
\text { changes? }\end{array}$ & & \\
\hline \multirow{2}{*}{ How to hire? } & How do the outsourced logistics operators & $\begin{array}{l}\text { What characteristic must the } \\
\text { logistics operator present? }\end{array}$ & \multirow{2}{*}{$\begin{array}{l}\text { Managers, public } \\
\text { employees of the SES- } \\
\text { MG and logistics } \\
\text { operator employees }\end{array}$} \\
\hline & work? What are the main contract clauses? & $\begin{array}{l}\text { What management tools } \\
\text { should be established? }\end{array}$ & \\
\hline \multirow{3}{*}{$\begin{array}{l}\text { What to } \\
\text { improvement in } \\
\text { the hiring? }\end{array}$} & $\begin{array}{l}\text { Which are the major difficulties and resistances } \\
\text { found in the change for this new model which } \\
\text { includes the logistics operator? }\end{array}$ & \multirow{3}{*}{$\begin{array}{l}\text { How to evaluate the results } \\
\text { (success of the outsourced } \\
\text { operation)? }\end{array}$} & \multirow{3}{*}{$\begin{array}{l}\text { Managers, public } \\
\text { employees of the SES- } \\
\text { MG and logistics } \\
\text { operator employees }\end{array}$} \\
\hline & $\begin{array}{l}\text { What were the actual results observed with the } \\
\text { implementation of this new model? }\end{array}$ & & \\
\hline & $\begin{array}{l}\text { Which are the disadvantages perceived from } \\
\text { hiring an outsourced logistics operator? }\end{array}$ & & \\
\hline
\end{tabular}

Source: Elaborated by the authors.

ample debate, in order to obtain broader impressions in regard to the logistics process adopted by the SES-MG. A few interview questions were based on Fleury et al. (2000) when deciding whether or not to hire a logistics operator. Table 1 presents this interaction.

After collecting the data, the interviews were transcribed and analyzed in order to achieve the objectives proposed in this study. In addition to the interviews many visits were made in order to understand the logistics process adopted by the SES-MG.

\section{RESULTS AND DISCUSSION}

The logistics operation process in the State of Minas Gerais attends all 853 municipalities of the State, encompassing a population of around 20 million people. The State Department of Health of Minas Gerais (SESMG) developed a classification of the distributed and stocked materials, according to its relevance, form of transportation, storage and its use. The classification is described in Table 2.

With the presented classification it is possible to infer that the logistics processes in question present varied complexities, comprehending purchase, transportation and storage from office materials to vaccines, serum and thermolabile products, which demand specific care, going through medications of diverse use and added value. The focus of this study was global medication purchase, transportation and storage logistics processes, presenting a new model with the implementation of the outsourced logistics operator.

The SES-MG logistics process begins with planning and the execution of the purchase. The purchase is centralized in the SES-MG and performed by public employees after consolidating all the demands from Managements Regional Health (MRH). While the receiving, storage and transportation in the new logistics model is performed by the outsourced logistics operator. The managers pointed out in their interviews the following factors which contributed to the decision of hiring a logistics operator: 1) the growth of medication distribution programs to the population; 2) the increase in the number of legal actions against the State demanding specific medications; 3) the increase in the investment in vaccination and disease prevention; and 4) the necessity of quicker actions in fighting epidemic surges. Such factors are directly associated to the increase in the demand for materials in the State in the previous years.

For being more complex in Public Administration then in private organizations, the purchase process continues being performed by the State, aiming at maintaining the competitiveness and impersonality of the licitation processes. Thus, the processes chosen for outsourcing were: receiving, storage, inventory, separation, transportation planning, expedition and distribution, as illustrated in Figure 2.

The previous medication logistics model of the State of Minas Gerais did not present a logistics operator. All activities were administered and executed by the SES- 
Table 2. Classification of the Materials of the State Department of Health of Minas Gerais (SES-MG).

\begin{tabular}{|c|c|c|}
\hline Type of medication & Definition & $\begin{array}{l}\text { Representativity in } \\
\text { total cost (\%) }\end{array}$ \\
\hline High cost medications & $\begin{array}{l}\text { Medications destined to the treatment of specific pathologies, which strike a } \\
\text { limited number of patients. In the majority of the cases, they consist in long- } \\
\text { term use and high added value medications. }\end{array}$ & 52 \\
\hline Strategic medications & $\begin{array}{l}\text { Medications used for grievances relating to specific programs of the Brazilian } \\
\text { Ministry of Health, these being financed by the Ministry itself and managed by } \\
\text { the State Secretariats. They comprehend the aniretrovirals, insulins, leprosy, } \\
\text { tuberculosis and focal endemics treatment medications. }\end{array}$ & 13 \\
\hline $\begin{array}{l}\text { Medications and } \\
\text { products derived from } \\
\text { legal action }\end{array}$ & $\begin{array}{l}\text { Medications or healthcare materials which the State must deliver to the patients } \\
\text { by lawful force and in emergency nature in most cases. They may vary from } \\
\text { personal hygiene items to high cost medications. }\end{array}$ & 10 \\
\hline Basic medications & $\begin{array}{l}\text { Essential and low cost medications, distributed in municipal pharmacies. } \\
\text { Consists in medications for hypertension, contraceptives, anti-allergic, } \\
\text { antibacterial, psychotropic, among others. }\end{array}$ & 12 \\
\hline $\begin{array}{l}\text { Thermolabile } \\
\text { products }\end{array}$ & $\begin{array}{l}\text { Consist of vaccines, serums, a few medications and products which must be } \\
\text { conditioned and distributed in acclimatized, refrigerated and frozen } \\
\text { environments with controlled temperature. They present a distinct classification } \\
\text { given their special storage and transportation conditions. }\end{array}$ & 12 \\
\hline General materials & $\begin{array}{l}\text { Office materials, publicity materials, medical-hospital materials, heritage goods, } \\
\text { electronics, informatics materials, among others. }\end{array}$ & 1 \\
\hline
\end{tabular}

Source: Research Data (2012).

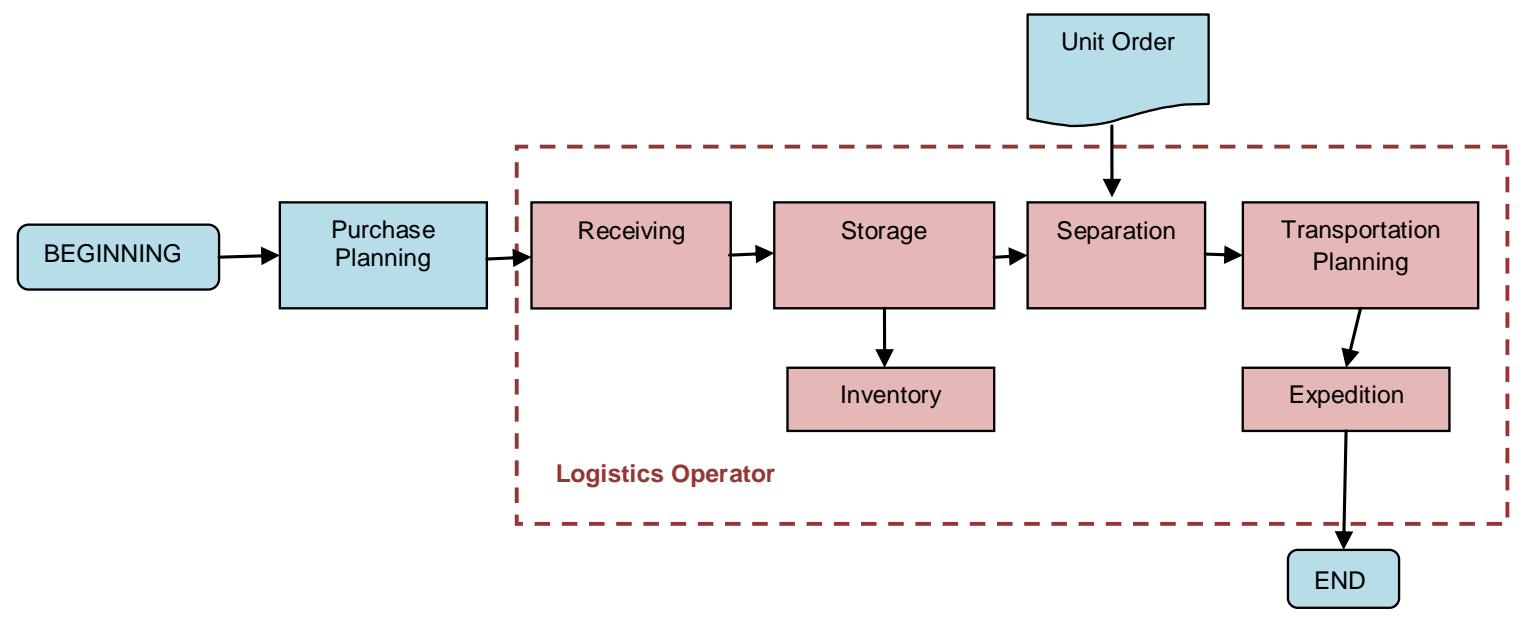

Figure 2. Outsourced logistics operator. Source: Research Data (2012).

MG. Medication receiving was performed by the SES-MG in Government property or leased warehouses. Employees were hired to work in storage and inventory, aiming at stock control. The SES-MG owned four central warehouses located in the capital of the State, the city of Belo Horizonte.

Some medications were distributed directly to the Medication Dispensation Unit, located in 853 


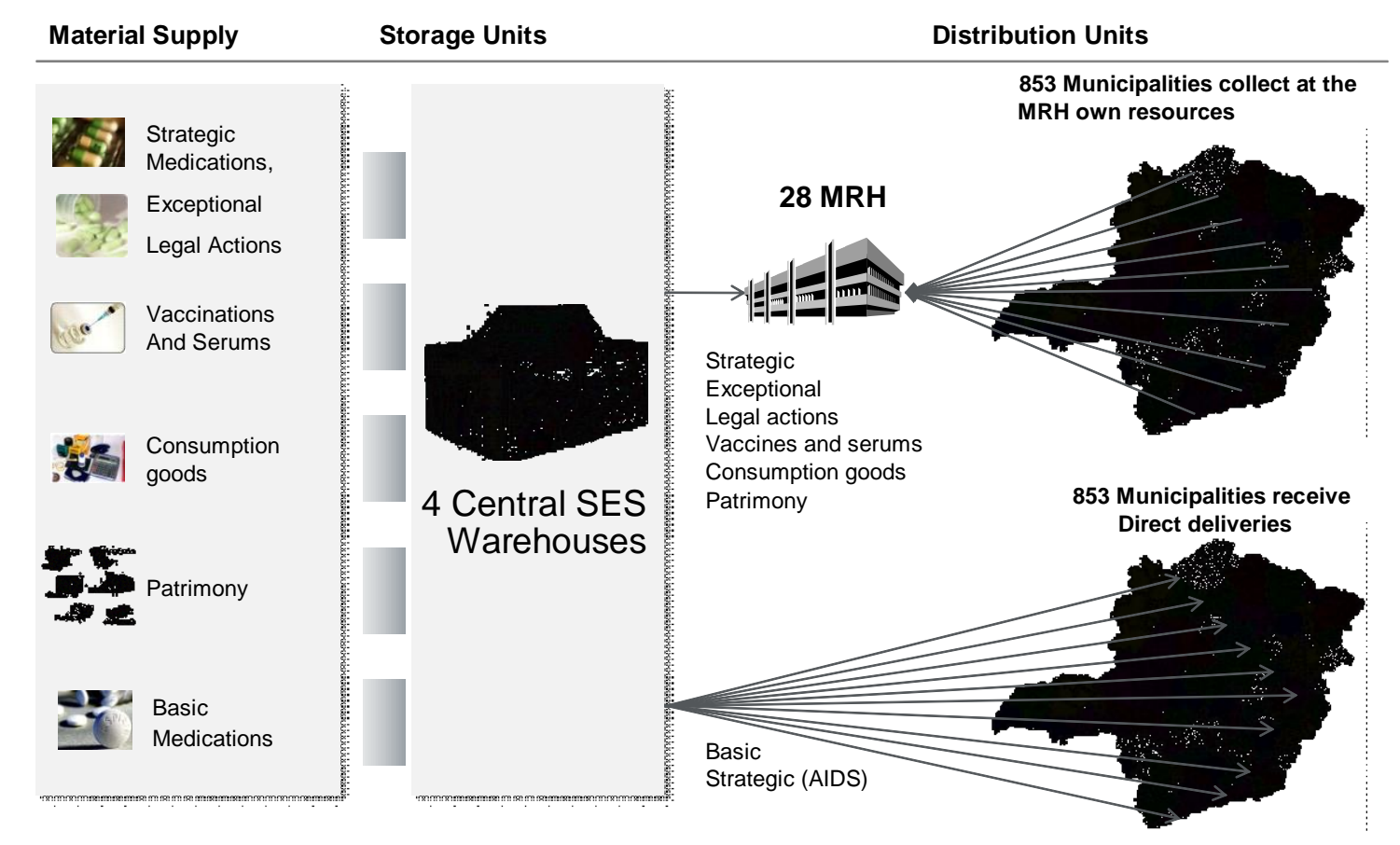

Figure 3. Previous model.

Source: Research Data (2012).

municipalities of the State, by the basic pharmacy program. Another part of the medications were delivered to the Managements Regional Health (MRH) in a consolidated manner, which centralized the distribution of the medications of the vaccination programs, the exceptional medications, those derived from legal actions and part of the strategic medications, for the cities under its jurisdiction.

The transportation was performed by the State Government's own fleet and, posteriorly, the Brazilian Postal and Telegraph Company, State organization, was hired for this activity. The freight was calculated based on the distance and the volume of the load.

A new medication logistics model of the State of Minas Gerais counts on a logistics operator and emphasizes modernization of the infrastructure and resources, rationalization of the costs and the improvement of the quality of the offered services in the development of logistic activities. The contract established with the logistics operator presents the time length of sixty months (five years). Such a validity period is in accordance with the law of licitation, which allows this maximum term for administrative contracts. However, the term is considered short by the managers involved in logistics, since there is the possibility of changing logistics operators every five years.

For a better comprehension, Figure 3 follows with the previous logistics model of the State of Minas Gerais. With the implementation of this new model, the storage and distribution operation in all the medication programs comes to being centralized in a single distribution center (CD). The Distribution Center is responsible for attending all units contemplated by the Pharmaceutical Assistance of the State Department of Health of Minas Gerais (SES$M G$ ), in addition to the administrative and functional units of the Organ itself, located in all the State. This means that the materials are received, treated and stored in this Distribution Center and from them they are sent to all over the State. Thus, the obligation of installing a hubs in the interior of the State is eliminated.

According to the managers interviewed, the gains are greater when all operations are concentrated in a single distribution center (CD). Therefore, the decision was to opt for single distribution center (CD) instead of four distribution centers. Centralizing the stock requires a lower storage area, maintenance costs of inventories are reduced and the capital invested in assets related to distribution centers (CD) is also lower. In contrast, the transportation costs increase due to greater distances between the municipalities and the single distribution center (CD). Thus, in this study, when analyzing these figures, we found that the option which offers the most advantage is the implementation of a single distribution center (CD).

Still in regard to the storage, the outsourced logistics operator possesses larger flexibility in case it is necessary to amplify the storage area, because there are no legal acquisition strains on the operator as there are 
Suppliers

Single Logistics Operator

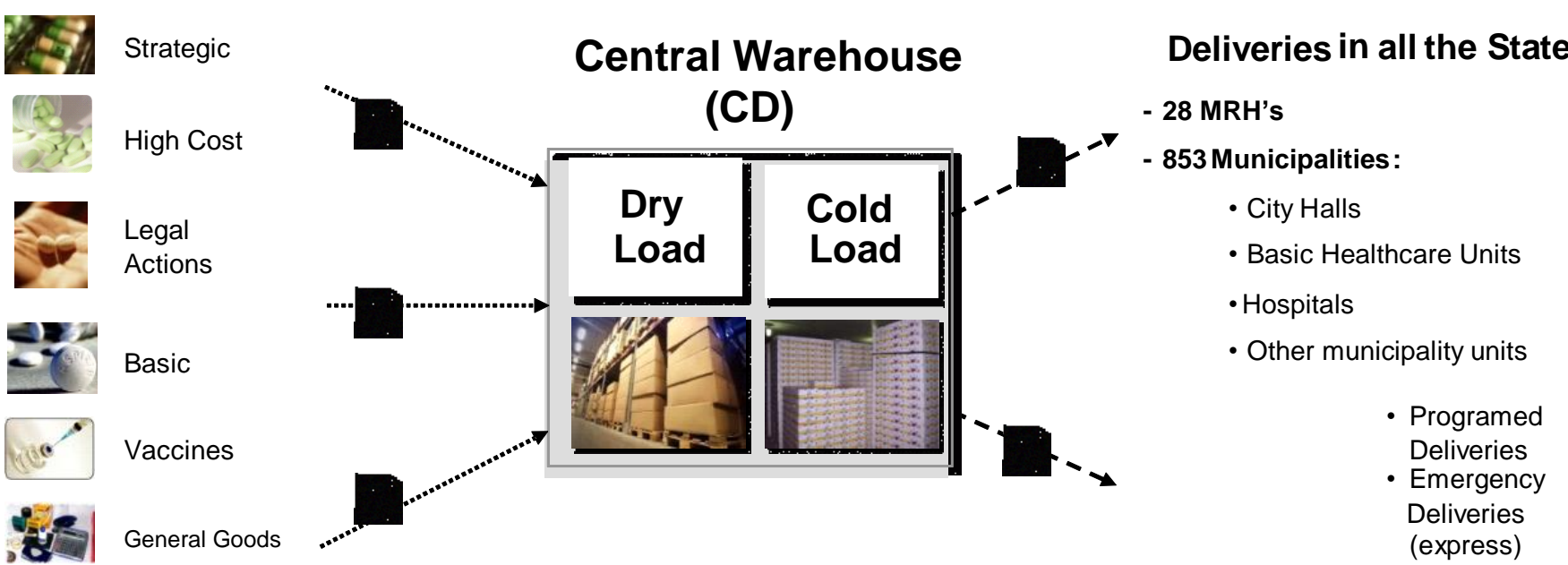

Figure 4. New models.

Source: Research Data (2012).

on the State. Due to the central location of the State's capital, and also due to the volume demanded from this region, the logistics operator opted for installing the distribution center in this region.

It is due noting that the warehouses must comply sanitary requisites established by Brazilian Health Surveillance Agency (ANVISA) and according to the conditions demanded for each type of medication. The security requisites of the process may also be considered a great point of advance. To exemplify, the logistics operator is obliged to install a circuitry of cameras in the storage space and the employees which transit in the warehouse must use pocket-less uniforms. A large advantage of the new model is the approximation with high technology. The logistics operator is specialized in the area and presents the largest conditions of presenting the best services.

In regard to the logistics operation processes related to transportation, it is due comparing them to the previous models adopted by the SES-MG. The previous model was inefficient, given that the fleet was small, with high maintenance cost and small possibility of expanding the fleet. Thus, the orders needed to be made with large antecedence, with little condition of emergency responses to new materials necessary to the municipalities.

The employment of the the Brazilian Postal and Telegraph Company to execute the transportation aimed at improving the response capacity to the SES-MG demands. However, the freight was considered high, since its calculation considered the distance, volume and weight of the load. Another issue that must be reinforced is that the Brazilian Postal and Telegraph Company did not differentiate between loads of distinct added value. In the case of healthcare items, for example, there are basic medications and high cost medications, which presented very different unit value. Thus, the model employed in the outsourced logistics operation also aimed at resolving this problem. Another highlighted point in the employment of an outsourced operator was the pricing form of the transportation. From the new contract, the freight is calculated according to the value of the load and the complexity of the transportation. That is, in this new arrangement, the operators' awarding is calculated by the risk he will take in transporting the items. It is important to highlight that, in the new model, the transporting vehicles are obliged to having load tracking, among other procedures which aim at diminishing loss by theft. Figure 4 presents the new logistics model which is being implemented in the State of Minas Gerais, Brazil.

The new model increases the quality of the services offered, through the Service Level Agreement. From the service level accorded, it is possible to note a large corporative gain with the new model. The deliveries with the own fleet took approximately seven weeks (49 days) to round the entire State with the medications, while in this contract, the maximum term falls to 30 days.

In addition, the new model was projected in a manner to centralize storage and distribution of all the medication programs and other materials distributed by SES-MG in a single Distribution Center. Thus, it is possible to concentrate the operation volumes, increase synergy and process sharing, simplify the management and the control of the logistics chain. Such a choice is aligned with goo practices, norms and active legislations for each material transited by this new Distribution Center. In this sense, one of the main positive factors is the integration 
Table 3. Advantages and disadvantages of implementing the Outsourced Logistics Operator.

\begin{tabular}{ll}
\hline Storage and Transportation & \\
\hline Advantages & Disadvantages \\
\hline$\checkmark \quad$ Specialized operator, with more experience in the field; & $\checkmark$ Contract term of five years is considered short for a \\
$\checkmark \quad$ Expansion and reduction of storage space with more & $\begin{array}{l}\checkmark \text { Work flow is still confusing; } \\
\text { agility; }\end{array}$ \\
$\checkmark \quad$ Storage of the demanded sanitary standards; & $\checkmark \quad$ Difficulties in managing outsourced contracts ; \\
$\checkmark \quad$ Inventory more faithful to the reality, thanks to the & $\checkmark \quad$ Resistance, especially by the employees working in \\
operator system; & the operational; \\
$\checkmark \quad$ Single distribution center, centralization of the logistic & $\checkmark \quad$ Little geographical knowledge of Minas Gerais, \\
processes; & especially in the more isolated delivery points \\
$\checkmark \quad$ High security standard and responsibility of material & \\
guarding; & \\
$\checkmark \quad$ Decrease of the time of delivery in the entire state; & \\
$\checkmark \quad$ Service level accordance by type of delivery, according & \\
to the size of the delivery municipality; & \\
$\checkmark \quad$ Load tracking technology; & \\
$\checkmark \quad$ Freight which takes into account the value of the load, & \\
rewarding the company by the risk; & \\
$\checkmark \quad$ Cut of costs in maintenance and operation of own & \\
vehicles. &
\end{tabular}

Source: Research Data (2012).

of the managerial systems of the State with the management system of the warehouse specified by the outsourced logistics operator. With this, the improvement of the processes which come to be the responsibility of the operator, such as inventory and transit inside the stock, is possible.

On the other hand, a few disadvantages are mentioned by the interviewed managers. The term of the logistics operators' contract is considered short by those involved in the process. Especially while considering the processes related to storage, the term is not satisfactory and opens doors to the possibility of a significant operational break every five years. However, there is no possibility of a longer contract term inside Public Administration.

Despite all the efforts of the SES-MG, there is still some confusion on the work flow, especially on the division of the responsibilities for certain logistics operation tasks. On the employer's point of view, this is due to the positioning difficulties while manager of outsourced contracts. The SES-MG did not possess much experience with this type of employment; therefore, it has been a few challenges in this area.

Another disadvantage observed is inherent to any process of change: the resistance. Many sectors of the SES-MG are still resistant to the changes and this makes it difficult for the implementation of the new model.

Table 3 presents the main advantages and dis-advantages for the outsourcing of the logistics operation perceived by the SES-MG.

Table 4 shows that the change in area logistics held in
SES-MG may be considered positive, since the expectations of the involved were met, such as cost reduction and improvement of logistic services. However, other problems arose with this new model, such as the difficulty of the SES-MG managing contracts and the conflict between the parties in regard to the responsibility of each one.

In a research conducted by Lambert et al. (1999) they mentioned the following failure factors of hiring a logistics operator: unrealistic expectations; cultural differences; lack of mutual benefits and profitability; lack of common goals; resistance; lack of organizational support; poorly established power; concerns with loss of control and uncertainty about the level of service; unjust price and cost; bad planning; lack of confidence; service inferior to the proposed; poor communication; failure to respond to changes in strategy and market conditions.

Other authors such as Bandeira et al. (2012) and Jané and Ochoa (2006) pointed out the flaws in the outsourcing contract as major impediment of the logistics operators market. The research conducted at SES-MG, identified difficulty in managing the outsourced contract, since the rules and responsibilities of each party were not well defined. Some bottlenecks observed by Lambert et al. (1999) were also confirmed in the study of SES-MG, such as the resistance and the confusing workflow which may be the result of cultural differences, lack of organizational support; poorly established power; poor planning; lack of trust; poor communication; failure to respond to changes in strategy and market conditions. 
Table 4. Summary of results.

\begin{tabular}{|c|c|c|}
\hline Subject & Interview questions & Summary of results \\
\hline Why hire? & $\begin{array}{l}\text { How was the project to hire an outsourced } \\
\text { logistics operator for SES-MG designed? } \\
\text { What are the idealized advantages with the } \\
\text { change in models and hiring of a logistics } \\
\text { operator? } \\
\text { What are your expectations with these } \\
\text { changes? }\end{array}$ & $\begin{array}{l}\text { The answers of the respondents made it clear that the } \\
\text { decision of hiring a logistics operator is due to the fact that } \\
\text { the old model did not satisfy the new public administration } \\
\text { management. The advantages idealized by those involved } \\
\text { in this process were cost reduction and the quality of } \\
\text { services provided by the logistics operator. Expectations } \\
\text { with this new change was to improve the quality of public } \\
\text { expenditure and increase its performance. }\end{array}$ \\
\hline How to hire? & $\begin{array}{l}\text { How do the outsourced logistics operators } \\
\text { work? What are the main contract clauses? }\end{array}$ & $\begin{array}{l}\text { The logistics operator uses high technology and a single } \\
\text { distribution center (CD) which was considered feasible by } \\
\text { all respondents. However, the term of the contract and the } \\
\text { conflicts between logistics operator and contractor were } \\
\text { highlighted in the interviews. Some respondents pointed } \\
\text { out that the workflow is still confusing; the responsibilities of } \\
\text { each employee in the process were not established. } \\
\text { Another issue which generates conflict is the lack of } \\
\text { geographical knowledge of the } 853 \text { municipalities by } \\
\text { employees of the logistics operator. Being an early stage of } \\
\text { the implementation of this new model, the more isolated } \\
\text { points of delivery, are not yet known to them, causing } \\
\text { dissatisfaction among employees of the SES-MG, since } \\
\text { this fact influences the result of team work. }\end{array}$ \\
\hline $\begin{array}{l}\text { What improvement in } \\
\text { hiring? }\end{array}$ & $\begin{array}{l}\text { Which are the major difficulties and } \\
\text { resistances found in the change for this } \\
\text { new model which includes the logistics } \\
\text { operator? } \\
\text { What were the actual results observed with } \\
\text { the implementation of this new model? }\end{array}$ & $\begin{array}{l}\text { The greatest difficulty presented by the interviewees in this } \\
\text { new scenario of SES-MG was the lack of experience in } \\
\text { managing outsourced contracts and the resistance of a few } \\
\text { staff members. The main disadvantages reported by the } \\
\text { majority of respondents were the term of the contract and } \\
\text { workflow which was still found confusing. Accordingly, the } \\
\text { SES-MG needs to review the contracts, further establishing } \\
\text { the rules and responsibilities of the parties. Besides } \\
\text { presenting cost reduction and improved quality of service, } \\
\text { this new model adopted by SES-MG contributed to the } \\
\text { integration of management systems, resulting in gains for } \\
\text { all areas. }\end{array}$ \\
\hline
\end{tabular}

Source: Research Data (2012).

The experience of this case aids in alerting other professionals and companies that are interested in implementing a similar logistic model, with regard to the difficulties faced in the process. There are some precautions that may be taken to avoid the kinds of problems encountered in this case study of SES-MG, such as a better preparation of the design and management of outsourced contracts (pay attention to the clauses, set rules and responsibilities of the parties); train employees with greater intensity for the paradigm shift, especially in the lower hierarchical and regional levels.

Before starting the process of implementing a new model, it is important to make a connection between the company's employees and the logistics operator employees. The purpose of performing this approach is to exchange information and build mutual trust. The lack of geographical knowledge of some municipalities reported in this study could be avoided with this approach. The employees of the contractor shall see the logistics provider as a partner, which aims at facilitating and improving the team result.

\section{Concluding remarks}

The objectives of this research were reached, since a description of the logistic process adopted by the State Department of Health of Minas Gerais (SES-MG) was made, in relation to the medication acquisition and distribution public politics of the State of Minas Gerais. In addition, the study performed a comparison of the previous model with the new model; and identified the 
main advantages and disadvantages of outsourcing the logistics operation referent to the medications in the State of Minas Gerais in Brazil.

Observing the State's purchase procedures, it was verified that the peculiar principals of competitiveness were preserved, but is little efficient in the relation between supplier and the State, as well as being a meticulous and time consuming process. However, it is a methodology with little possibility of changing.

Analyzing the transportation service management, it was possible to infer that the transportation represents a significant cost inside total logistic costs. Therefore, in relation to such process, the employment of a logistics operator offers a better integration between suppliers, buyers and scheduled deliveries, making so that the cost is lower than in the previous model.

In regard to stock and storage, the theory points that maintaining a warehouse involves large costs and effort, especially while considering seasonality of the healthcare products over the year. Therefore, the presented alternative is the use of public (or shared) warehousesor even outsourcing the operation, transferring part of the risks to an organization specialized in the field.

In regard to the implementation of the SES-MG's new logistics model, a great expectancy of general improvement was observed of the interviewed managers. In fact, the model presented significant advantages that, in the end, were emphasized to the transportation and storage strands.

The resistance to the change into the new model is a fact which inspires caution. The SES-MG needs to continue its redesigning process in this new context, aiming at overcoming these challenges, for the gains are superior the disadvantages. In this new model it is possible to that the citizen receive the medication in a shorter time and with higher security. The outsourced logistics operator presents specialization and more technology in the processes, and this contributes to offering a better quality service.

Another difficulty mentioned in this study for the successful implementation of the new model is the lack of experience of SES-MG as manager of outsourced contracts. Thus, this study provides a reflection on hiring a logistics operator. Before hiring anyone it is important for the contractor to analyze the costs, benefits and compare which option is best: perform or outsource logistics activities. If the option is to outsource some actions are important in this process to achieve better performances, such as requiring intensive exchange of information between the contractor and the logistics operator; define the strategy to be followed by the contractor in relation to the procurement model; detail on contract the levels of responsibilities and authorities between the parties (setting rules, incentives, rewards and penalties to the contractor due to unmet expectations of the contractor); guide the contractor into monitoring the outsourced activities and conduct ongoing monitoring; specify the expected results and targets for contracting the services of a logistics operator.

At the end of this research, a few gaps in knowledge were presented for future studies. The study on advanced logistics cost associated to the outsourcing of the logistics operator is still in analysis in the State. In addition, this study was based only on the experience that the SES-MG obtained since the implementation of the new model. It is due noting that the implementation of this new model began in 2012 and is still in a restructuring phase.

\section{REFERENCES}

Abrucio FL (2005). The advances and dilemmas of post-bureaucratic model: the reform of public administration in the light of recent international experience. (Org.): Bresser-Pereira LC, Spink P. In: Reform of the state and public administration management. São Paulo: Fundação Getúlio Vargas.

Baily P, Farmer D, Jessop D, Jones D (2000). Purchase: Principles and Management São Paulo: Atlas.

Ballou RH (2001). Supply chain management: planning, organization and logistics. Porto Alegre: Bookman.

Bandeira RAM, Mello LCBB, Maçada ACG (2012). Elementos de flexibilidade em contratos de terceirização logística: o caso de uma empresa de telecomunicações. Revista Produção 22(2):237-248.

Bossert TJ, Bowser DM, Amenyah JK (2007). Is decentralisation good for logistics systems? Evidence on essential medicine logistics in Ghana and Guetemala. Health Policy Plann. 22(2):73-82.

Bowersox DJ, Closs DJ, Cooper MB (2007). Supply Chain Management and Logistics. Rio de Janeiro: Elsevier.

Bresser-Pereira LC (2005). From bureaucratic public administration to management. (Org.): Bresser-Pereira LC, Spink PK. In: State Reform and Public Administration management. Rio de Janeiro: Fundação Getúlio Vargas.

Buss PM (2000). Promoting health and quality of life. Ciência Saúde Coletiva 5(1):63-77.

Chindove S, Mdege ND (2012). Logistics Data Collection and Reporting for Essential Medicines in Developing Countries: A Review. J. Health Manage. 14(4):397-408.

Christopher M (2001). Logistics and supply chain management: strategies for reducing costs and improving services. São Paulo: Pioneira Thomson Learning.

Denhardt RB (2012). Theories of public administration. São Paulo: Cengage Learning.

Di Pietro MSZ (1998). Administrative Law. São Paulo: Atlas.

Fleury PF, Wanke P, Figueiredo KF (2000). Logística empresarial. São Paulo: Atlas, 2000.

Fleury PF, Wanke P, Figueiredo KF (2003). Logistics and Supply Chain Management: Planning Flow Products and Resources. São Paulo: Atlas.

Hill A (2003). de Distribuição: estratégia para redução de custos e garantia de entrega rápida e eficaz. 4a Conferência sobre logística colaborativa.

Jané H, Ochoa A (2006). The handbook of logistics contracts: a practical guide to a growing field. Hampshire: Macmillan Publishers.

Lambert DM (1998). Administração Estratégica da logística. São Paulo: Vantine Consultoria.

Lambert DM, Emmelhainz MA, Gardner JT (1999). Building Successful Logistics Partnerships. J. Bus. Logist. 20(1):165-182.

Machline C, Amaral Jr. JBC (1998). Advances in domestic retail logistics: the case of pharmacy chains. Revista de Administração de Empresas 38:63-71.

Mello CAB (2007). Administrative Law Course. São Paulo: Malheiros Editores. 
Mentzer JT, Dewitt W, Keebler JS, Min S, Nix NW, Smith CD, Zacharia ZG (2011). Defining supply chain management. J. Bus. Logist. 22(2):1-25.

Novaes AG (2001). Logistics and supply chain management: strategy, activities and assessment. Rio de Janeiro: Campus.

Nwokah NG, Maclayton DW, Ezirim AC (2009). Logistics and Distribution of Drugs in Government Owned Hospital in Nigeria. Int. J. Afr. Stud. 1:36-42.

Oliveira S (2004). Treaty of Scientific Methodology, Research Projects, TGI, TCC, Papers, Dissertations and Theses. São Paulo: Pioneira Thomson Learning.

Oliveira EA, Labra ME, Bermudez J (2006). Public production of medicines in Brazil: an overview. Caderno de Saúde Pública 22(11):12-27.

Osborne D, Gaebler T (1997). Reinventing Government: How the entrepreneurial spirit is transforming the public sector. Brasília: $\mathrm{MH}$ Comunicação.

Pan American Health Organization / World Health Organization (2005). Evaluation of Pharmaceutical care in Brazil: structure, process and outcomes. Brasília: Ministry of Health.

Portela AS, Leal AAF, Werner RPB, Simões MOS, Medeiros ACD (2010). Public policies for drugs, trajectory and challenges 31(1):0914.
Sarlet IW (2007). Some considerations about the content, efficacy and effectiveness of health rights in the 1988 Constitution. Revista Eletrônica Sobre a Reforma do Estado 11:1-17.

Tetteh E (2009). Creating reliable pharmaceutical distribution networks and supply chains in African countries: Implications for access to medicines. Res. Soc. Adm. Pharm. 5(3):286-297.

Tridapalli JP, Fernandes E, Machado WV (2011). Supply chain management in the public sector: an alternative for control of curren spending in Brazil. Revista de Administração Pública 45 (2):401-433.

Valente AM, Novaes AG, Passaglia E, Vieira H (2008). Transportation Management and Fleet. São Paulo: Cengage Learning.

Vaz JC, Lotta GS (2011). The contribution of integrated logistics decisions of public policy management in Brazil. Revista de Administração Pública 45:107-139.

Vergara SC (2010). Projects and Research Reports in Management. São Paulo: Atlas.

Viana JJ (2000). Materials Management: a practical approach. São Paulo: Atlas. 